\title{
Melanocortin 2 receptor antagonists in canine pituitary-dependent hypercortisolism: in vitro studies
}

\author{
Karin Sanders ${ }^{1}$ (D) $\cdot$ Jan A. Mol $^{1} \cdot$ Hans S. Kooistra $^{1} \cdot$ Sara Galac $^{1}$ \\ Received: 22 May 2018 / Accepted: 30 August 2018 / Published online: 5 September 2018 \\ (C) The Author(s) 2018
}

\begin{abstract}
Canine hypercortisolism is most often caused by an ACTH-secreting pituitary adenoma (pituitary-dependent hypercortisolism; PDH). An interesting target for a selective medical treatment of PDH would be the receptor for ACTH: the melanocortin 2 receptor (MC2R). In this study we investigated whether two peptide compounds, BIM-22776 (\#776) and BIM-22A299 (\#299), are effective MC2R antagonists in vitro. Their effects on cortisol production and mRNA expression of steroidogenic enzymes, MC2R and melanocortin 2 receptor accessory protein (MRAP) were evaluated in primary adrenocortical cell cultures $(n=8)$ of normal canine adrenal glands. Cortisol production stimulated by $50 \mathrm{nM} \mathrm{ACTH}$ was dose-dependently inhibited by \#299 (inhibition $90.7 \pm 2.3 \%$ at $5 \mu \mathrm{M}$ ) and by \#776 (inhibition $38.0 \pm 5.2 \%$ at $5 \mu \mathrm{M}$ ). The ACTH-stimulated mRNA expression of steroidogenic enzymes, MC2R and MRAP was significantly inhibited by both compounds, but most potently by \#299. These results indicate that canine primary cell culture is a valuable in vitro system to test MC2R antagonists, and that these compounds, but especially \#299, are effective MC2R antagonists in vitro. To determine its efficacy in vivo, further studies are warranted. Antagonism of the MC2R is a promising potential treatment approach in canine PDH.
\end{abstract}

Keywords Cushing's syndrome $\cdot$ PDH $\cdot$ Treatment $\cdot$ ACTH $\cdot$ MC2R $\cdot$ Dog

\section{Introduction}

Hypercortisolism (Cushing's syndrome) is one of the most frequently diagnosed endocrinopathies in dogs (Galac et al. 2010c). This serious endocrine disorder is characterized by chronic exposure to excessive amounts of glucocorticoids, which can be caused by either glucocorticoid administration or endogenous cortisol overproduction. Endogenous hypercortisolism occurs in approximately 1 to 2.5 per 1000 dogs per year (Willeberg and Priester 1982; O'Neill et al. 2016), and is most frequently $(\sim 80-85 \%)$ caused by an ACTH-producing pituitary adenoma (pituitary-dependent hypercortisolism; PDH) (Galac et al. 2010c).

The current drug of choice for the medical treatment of canine PDH is trilostane, which competitively inhibits the steroidogenic enzyme $3 \beta$-hydroxysteroid dehydrogenase type

Karin Sanders

k.sanders@uu.nl

1 Department of Clinical Sciences of Companion Animals, Faculty of Veterinary Medicine, Utrecht University, Yalelaan 108, 3584 CM Utrecht, the Netherlands
2 (HSD3B2) (Potts et al. 1978; Ramsey 2010). However, HSD3B2 is required for all classes of adrenocortical hormones and therefore not only inhibits the production of cortisol but also that of aldosterone (Galac et al. 2010a; Reid et al. 2014). Although trilostane is generally well tolerated, hypoadrenocorticism can occur (King and Morton 2017), and adrenal necrosis might occur more commonly than generally thought (Reusch et al. 2007), possibly due to increased ACTH secretion (Burkhardt et al. 2011). A more selective treatment option where the negative effects of increased ACTH secretion are countered could therefore improve the current medical treatment of canine PDH.

An interesting target for a more selective medical treatment of PDH would be the receptor for ACTH: the $\mathrm{G}_{\mathrm{s} \alpha}$-proteincoupled melanocortin 2 receptor (MC2R) (Mountjoy et al. 1992). The MC2R is expressed in all zones of the adrenal cortex, but its major function is to stimulate the zona fasciculata cells to produce cortisol (Clark et al. 2016; Sanders et al. 2016). The MC2R is one of five melanocortin receptors: MC1R-MC5R, which are all activated by melanocortin peptides that are derived from the precursor pro-opiomelanocortin (Bicknell 2008). The MC2R is unique in its ligand selectivity: while multiple melanocortin peptides 
can bind to the other MC receptors, only ACTH binds to the MC2R (Cerdá-Reverter et al. 2012; Dores et al. 2014). The MC2R needs to be transported from the endoplasmic reticulum to the cell surface, for which it requires the melanocortin 2 receptor accessory protein (MRAP). MRAP forms a complex with the MC2R which allows the MC2R to leave the endoplasmic reticulum and reach the cell surface, and which is necessary for binding of ACTH to the MC2R (Cooray et al. 2011; Cerdá-Reverter et al. 2012). This binding activates the cAMP-protein kinase A pathway which facilitates cholesterol transport to the inner mitochondrial membrane and the phosphorylation of several transcription factors. These activated transcription factors then increase the availability of free cholesterol and the transcription of genes encoding for steroidogenic enzymes, which eventually results in increased cortisol production (Stocco 1997; Ruggiero and Lalli 2016).

Consequently, a potent MC2R antagonist would be a great new treatment option to selectively inhibit ACTH-dependent hypercortisolism. The aim of this study was to evaluate whether the two peptide compounds BIM-22776 (\#776) and BIM-22A299 (\#299) are potent MC2R antagonists in vitro, and to determine whether MC2R antagonists have potential as a future treatment option for canine PDH.

\section{Materials \& methods}

\section{Animals \& tissues}

The adrenal glands of eight healthy dogs were used. The dogs were euthanized for reasons unrelated to this study, which was approved by the Ethical Committee of Utrecht University. The dogs were between 18 and 48 months of age (median 23 months), two were mongrels and six were beagles. One dog was female and seven were male, all of the dogs were sexually intact.

\section{Primary cell culture}

The adrenocortical cell suspensions were prepared as described previously (Sanders et al. 2018). In short, the adrenal cortices were digested in a collagenase solution, then filtered and washed. The cell suspensions were diluted to $1 \times 10^{5}$ cells/mL with DMEM F-12 (Gibco, Invitrogen, Breda, the Netherlands) with $1 \%$ Insulin-Transferrin-Selenium (Gibco), $0.125 \%$ BSA, $2.5 \% \mathrm{Nu}$-Serum (Corning, Amsterdam, the Netherlands) and $1 \%$ penicillin/streptomycin, and seeded in Multiwell 96 well plates $\left(100 \mu \mathrm{L}\right.$ per well) (Primaria ${ }^{\mathrm{TM}}$, Corning).

Two 96 well plates were used for each adrenal cell suspension: one plate for cortisol/DNA ratio measurements and one plate for reverse transcription quantitative PCR (RT-qPCR) analysis. The cells were left to attach for 4 to 7 days at
$37{ }^{\circ} \mathrm{C}$ in a humidified atmosphere of $95 \%$ air and $5 \% \mathrm{CO}_{2}$, after which the culture medium was refreshed prior to compound incubations.

Stock solutions of $500 \mu \mathrm{M}$ were prepared for compounds \#776 and \#299, dissolved in $10 \mathrm{mM} \mathrm{HCl}$. The cells were incubated with $50 \mathrm{nM}$ ACTH (1-24) (Synacthen®, Sigmatau BV, Utrecht, the Netherlands) and $50 \mathrm{nM}, 500 \mathrm{nM}$ and $5 \mu \mathrm{M}$ of \#776 and \#299. To determine whether the compounds would only affect cortisol production when ACTH(1-24) was added, cells were also incubated without ACTH(1-24) and with $5 \mu \mathrm{M}$ of \#776 and \#299. Incubations were performed in quadruplicate. After $24 \mathrm{~h}$ of incubation, cortisol concentrations were measured in the culture medium of four wells per condition by radioimmunoassay as described previously (Meijer et al. 1978).

\section{DNA measurements}

To correct for differences in number of cells per well, DNA was measured in each well to calculate cortisol/DNA ratios. After removing the culture medium, the culture plates underwent three freeze/thaw cycles, after which $50 \mu \mathrm{L}$ Tris/ EDTA (10 mM Tris, 1 mM EDTA, pH 8.0) was added to each well. The Qubit ${ }^{\circledR}$ dsDNA HS Assay Kit (Fisher Scientific, Landsmeer, the Netherlands) was used according to the manufacturer's instructions and DNA concentrations were measured with the Qubit ${ }^{\circledR} 2.0$ Fluorometer (Fisher Scientific). The cortisol/DNA ratios were calculated of four wells per condition, of which the results were averaged prior to statistical analysis.

\section{RT-qPCR}

After removing the culture medium, the wells for each condition were pooled and RNA was isolated from the cells with the RNeasy Micro Kit (QIAGEN, Venlo, the Netherlands), including the DNase treatment, according to the manufacturer's instructions. RNA concentrations were measured with NanoDrop (ND-1000, Isogen Life Science, Utrecht, the Netherlands), after which cDNA was synthesized from 500 ng total RNA with the iScript ${ }^{\mathrm{TM}}$ cDNA Synthesis Kit (Bio-Rad) according to protocol. The cDNA was subsequently diluted to $1 \mathrm{ng} / \mu \mathrm{L}$. RT-qPCR analysis was used to determine the mRNA expression of eight genes: steroidogenic acute regulatory protein (StAR), cytochrome P450 side chain cleavage (CYP11A1), HSD3B2, 17a-hydroxylase/17,20-lyase (CYP17), 21-hydroxylase (CYP21), 11ß-hydroxylase cytochrome P450 (CYP11B1), MC2R and MRAP (primers shown in Table 1). Optimization and confirmation of the primer specificity were performed as described previously (Galac et al. 2010b).

To correct for differences in cDNA concentrations, Ribosomal protein S19 (RPS19), succinate dehydrogenase complex subunit A (SDHA), hypoxanthine-guanine 
Table 1 Primers used for RTqPCR

\begin{tabular}{|c|c|c|c|}
\hline Target gene & Primer sequence $\left(5^{\prime} \rightarrow 3^{\prime}\right)$ & Product size (bp) & Annealing $\operatorname{Tm}\left({ }^{\circ} \mathrm{C}\right)$ \\
\hline \multirow[t]{2}{*}{ StAR } & Fw: CTC TGC TTG GTT CTC GG & 125 & \multirow[t]{2}{*}{62.5} \\
\hline & $\begin{array}{l}\text { Rv: CCT TCT TCC AGC CTT CC } \\
\text { Fw: CAC CGC CTC CTT AAA AAG TAA CAA G }\end{array}$ & \multirow[t]{2}{*}{129} & \\
\hline CYP11A1 & $\begin{array}{l}\text { Rv: GCT GCG TGC CAT CTC GTA G } \\
\text { Fw: CCT GCG GCC CCT ATG CTC }\end{array}$ & & 63.3 \\
\hline CYP17 & $\begin{array}{l}\text { Rv: GGC CGG TAC CAC TCC TTC TCA } \\
\text { Fw: CAG GAG GGT TTC TGG GTC AG }\end{array}$ & 134 & 60.0 \\
\hline HSD3B2 & Rv: AGG CTC TCT TCA GGC ACT GC & 186 & 56.5 \\
\hline CYP21 & Fw: AGC CCG ACC TTC CCC TCC ACC TG & 152 & \multirow[t]{2}{*}{64.5} \\
\hline CYP11B1 & $\begin{array}{l}\text { Rv: TCT GCC GGC GAA GTC CAC CCA TTT } \\
\text { Fw: GCC TAC CCC TTG TGG ATG AC }\end{array}$ & \multirow[t]{2}{*}{126} & \\
\hline \multirow[t]{2}{*}{$\mathrm{MC} 2 \mathrm{R}$} & $\begin{array}{l}\text { Rv: CTC TGT GAC TGC TGT CTG GG } \\
\text { Fw: TCA TGT GGT TTT GCC GGA AGA GAT }\end{array}$ & & 62.0 \\
\hline & $\begin{array}{l}\text { Rv: AAT GGC CAG GCT GCA AAT GAA A } \\
\text { Fw: CAC AGG TGA GGA ACA ACG }\end{array}$ & 138 & 58.5 \\
\hline MRAP & $\begin{array}{l}\text { Rv: ATC GAA GGT CAG TCC TGG } \\
\text { Fw: CCT TCC TCA AAA AGT CTG GG }\end{array}$ & 227 & 64.6 \\
\hline RPS19 & $\begin{array}{l}\text { Rv: GTT CTC ATC GTA GGG AGC AAG } \\
\text { Fw: GCC TTG GAT CTC TTG ATG GA }\end{array}$ & 95 & 61.0 \\
\hline SDHA & $\begin{array}{l}\text { Rv: TTC TTG GCT CTT ATG CGA TG } \\
\text { Fw: AGC TTG CTG GRG AAA AGG AC }\end{array}$ & 92 & 58.0 \\
\hline \multirow[t]{2}{*}{ YWHAZ } & $\begin{array}{l}\text { Rv: TTA TAG TCA AGG GCA TAT CC } \\
\text { Fw: CGA AGT TGC TGC TGG TGA }\end{array}$ & 104 & \multirow[t]{2}{*}{58.0} \\
\hline & Rv: TTG CAT TTC CTT TTT GCT GA & 94 & \\
\hline
\end{tabular}

phosphoribosyltransferase (HPRT) and tyrosine 3monooxygenase/tryptophan 5-monooxygenase activation protein zeta (YWHAZ) were used as reference genes (primers shown in Table 1) (Brinkhof et al. 2006; Stassen et al. 2015).

SYBRgreen supermix (Bio-Rad) was used for the RT-qPCR reactions, and amplification was performed using a CFX 384 Touch $^{\text {TM }}$ Real-Time PCR Detection System (Bio-Rad) with the following cycle parameters: initial denaturation for $3 \mathrm{~min}$ at $95^{\circ} \mathrm{C}$, then 40 cycles of $10 \mathrm{~s}$ at $95{ }^{\circ} \mathrm{C}$ followed by $30 \mathrm{~s}$ at the primerspecific optimal annealing temperature, and ending with melting curve analysis by one cycle of $10 \mathrm{~s} 95{ }^{\circ} \mathrm{C}$ and a temperature increment of $0.5^{\circ} \mathrm{C}$ for $5 \mathrm{~s}$ from $65^{\circ} \mathrm{C}$ to $95^{\circ} \mathrm{C}$. To exclude the possibility of interfering genomic DNA, for each sample a control where no reverse transcriptase was added in the cDNA reaction was analyzed. Data were analyzed with CFX Manager 3.1 (BioRad). Two technical replicates were used for each sample. GeNorm software (Vandesompele et al. 2002) was used to analyze expression levels of the reference genes, which justified their use. To calculate the normalized relative expression of each target gene, the $2^{-\Delta \Delta \mathrm{Ct}}$ method (Livak and Schmittgen 2001) was used.

\section{Statistical analysis}

Logarithmic transformation resulted in normally distributed data, which was confirmed with the Shapiro-Wilk test. After logarithmic transformation, cortisol/DNA ratios and RT-
qPCR fold changes were analyzed with repeated measures ANOVA with a Bonferroni post-hoc test to correct for multiple comparisons. A $p$ value of $<0.05$ was considered significant. Data are reported as mean \pm SEM of eight individual cell cultures.

\section{Results}

\section{Cortisol production: cortisol/DNA ratios}

Incubation with $50 \mathrm{nM} \mathrm{ACTH(1-24)} \mathrm{increased} \mathrm{the} \mathrm{cortisol/}$ DNA ratio $35.4 \pm 10.4$-fold $(p<0.0001)$. Co-incubation with \#776 dose-dependently inhibited the ACTH-stimulated cortisol/DNA ratio by $33.5 \pm 7.1 \%$ at $500 \mathrm{nM}$ and by $38.0 \pm$ $5.2 \%$ at $5 \mu \mathrm{M}$ (Fig. 1A). Co-incubation with \#299 dosedependently inhibited the ACTH-stimulated cortisol/DNA ratio by $25.1 \pm 5.0 \%$ at $50 \mathrm{nM}$, by $78.8 \pm 7.2 \%$ at $500 \mathrm{nM}$ and by $90.7 \pm 2.3 \%$ at $5 \mu \mathrm{M}$ (Fig. $1 \mathrm{~A}$ ).

In the non-ACTH-stimulated cells, neither compound inhibited the cortisol/DNA ratio. On the contrary, \#776 slightly but significantly $(p=0.002)$ increased the nonACTH-stimulated cortisol/DNA ratio $1.4 \pm 0.1$-fold at $5 \mu \mathrm{M}$ (Fig. 1B). Compound \#299 did not affect the nonACTH-stimulated cortisol/DNA ratio $(1.1 \pm 0.1$-fold, $P=$ 1) (Fig. 1B). 

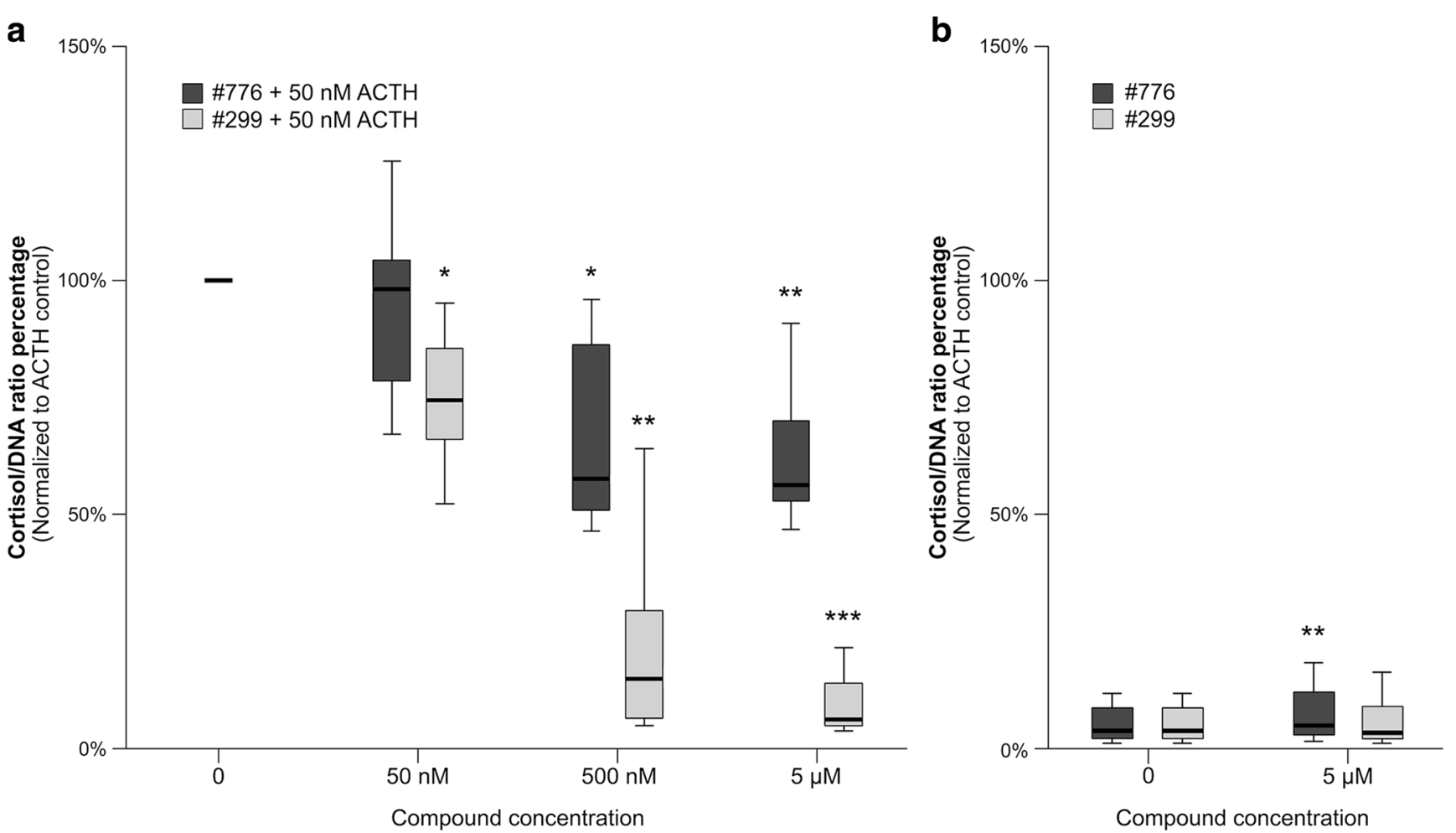

Fig. 1 The effects of compounds BIM-22776 (\#776) and BIM-22A299 (\#299) on the cortisol production of $\mathrm{ACTH}(1-24)$-stimulated (A) and non-ACTH-stimulated (B) canine primary adrenocortical cell cultures $(n=8)$. Cortisol/DNA ratios are shown in percentages, normalized to

the ACTH-stimulated control. Asterisks represent significant differences compared to the ACTH-stimulated controls: $* P<0.05, * * P<0.01$, $* * * P<0.001$

\section{RT-qPCR}

Incubation with $50 \mathrm{nM} \mathrm{ACTH}(1-24)$ significantly $(P<0.01$ or lower) upregulated the mRNA expression of all the genes analyzed in this study, but most notably that of CYP17, followed by MRAP, CYP11B1 and StAR (Fig. 2). Coincubation with $5 \mu \mathrm{M} \# 776$ significantly inhibited the ACTH-stimulated expression of five of the eight genes analyzed in this study (Fig. 2), while co-incubation with $5 \mu \mathrm{M}$ \#299 significantly inhibited the ACTH-stimulated expression of all the genes analyzed in this study (Fig. 2).

\section{Discussion}

The results of this study show that canine primary adrenocortical cell culture stimulated with synthetic $\mathrm{ACTH}(1-24)$ is a functional in vitro model to test the efficacy of MC2R antagonists. Moreover, this study shows that \#299 and \#776 are effective MC2R antagonists, of which \#299 is the most potent.

Multiple attempts to create or isolate MC2R antagonists have been made previously (Seelig and Sayers 1973; Yang et al. 1997; Dores 2013), mostly with varying effects. Recently, Bouw et al. (2014) showed that GPS1573 and GPS1574, two ACTH analogs, can antagonize MC2R in vitro in the nanomolar range in a human embryonic kidney

cell line transfected with the MC2R (Bouw et al. 2014). However, a subsequent study by Nensey et al. (2016) demonstrated that GPS1573 could not antagonize the adrenal response to ACTH in neonatal rats in vivo. High concentrations of GPS1574 did dose-dependently inhibit corticosterone production in these rats (Nensey et al. 2016). Whether \#776 and \#299 can antagonize the adrenal response to ACTH in vivo remains to be determined, but using primary adrenocortical cell cultures might be a better predictor of in vivo functionality than using homogeneous and genetically altered cell lines from extra-adrenal sources.

In this study we evaluated how the compounds affected the cortisol production of both ACTH-stimulated and nonACTH-stimulated cells. We aimed to mimic ACTHdependent hypercortisolism by adding $50 \mathrm{nM}$ synthetic ACTH(1-24). This ACTH concentration significantly and strongly increased the cortisol production, which indicates that the cells responded as expected and that canine primary adrenocortical cell culture is a good in vitro model to test the effects of ACTH. Because we corrected the cortisol values with the DNA concentrations, we could exclude the possibility that any observed differences in the cortisol production were caused by a difference in the number of cells.

In the non-ACTH-stimulated canine adrenocortical cells, incubation with \#776 slightly but significantly increased the cortisol production, which could indicate that \#776 has 


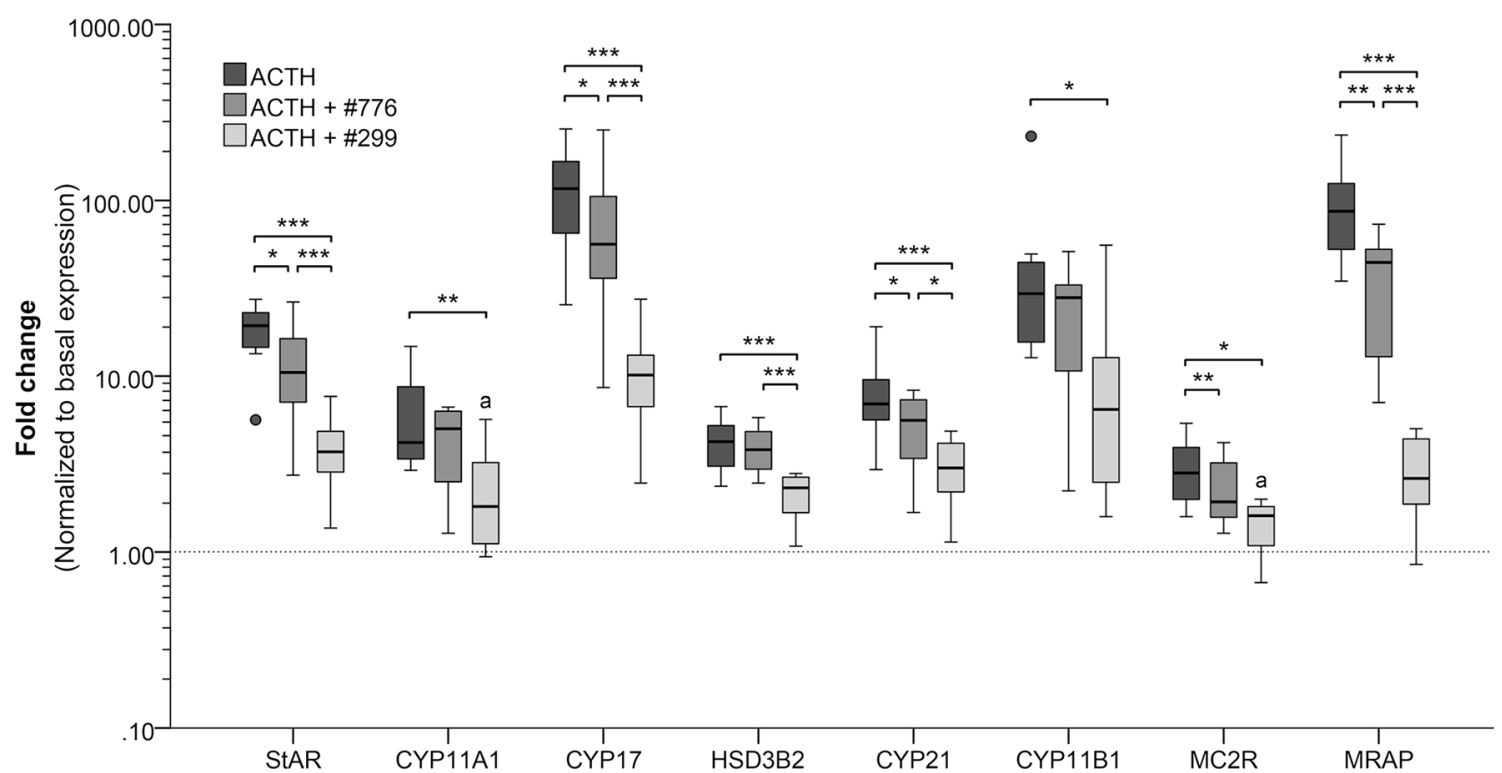

Fig. 2 The effects of incubation with $50 \mathrm{nM} \mathrm{ACTH}(1-24)$ and of coincubation of $\mathrm{ACTH}(1-24)$ with $5 \mu \mathrm{M}$ of compounds BIM-22776 (\#776) and BIM-22A299 (\#299) on the relative mRNA expression of steroidogenic enzymes, MC2R, and MRAP in canine primary adrenocortical cell cultures $(n=8)$. Fold changes are normalized to the non-ACTHstimulated controls, i.e. the basal expression. Asterisks represent significant differences: $* P<0.05, * * P<0.01, * * * P<0.001$. All conditions were significantly different from the basal expression, except when indicated with an "a". StAR, steroidogenic acute regulatory protein; CYP11A1, cytochrome P450 side chain cleavage; CYP17, 17 $\alpha$-hydroxylase/17,20-lyase; HSD3B2, 3 $\beta$-hydroxysteroid hydrogenase type 2 ; CYP21, 21-hydroxylase; CYP11B1, 11 -hydroxylase cytochrome P450; MC2R, melanocortin 2 receptor; MRAP, melanocortin type 2 accessory protein

\section{Conclusion}

In conclusion, the results of this study indicate that canine primary cell culture is a valuable in vitro system to test MC2R antagonists, and that these compounds, but especially \#299, are effective MC2R antagonists in vitro. To determine their efficacy in vivo, further studies are warranted. Antagonism of the $\mathrm{MC} 2 \mathrm{R}$ is a promising potential treatment approach in canine PDH.

Acknowledgements The authors thank Dr. Maria Ufret, Dr. Heather A. Halem and Dr. Michael D. Culler from Ipsen Bioscience, Inc. for kindly providing the compounds and for their expertise. We thank Adri Slob for the cortisol measurements and technical assistance.

Funding This work was supported by Morris Animal Foundation [D15CA-052].

\section{Compliance with ethical standards}

Conflict of interest The authors have no conflicts of interest to declare.

Open Access This article is distributed under the terms of the Creative Commons Attribution 4.0 International License (http:// creativecommons.org/licenses/by/4.0/), which permits unrestricted use, distribution, and reproduction in any medium, provided you give appropriate credit to the original author(s) and the source, provide a link to the Creative Commons license, and indicate if changes were made. the $\mathrm{MC} 2 \mathrm{R}$, and do not affect the other melanocortin recep tors. This compound selectivity will have to be determined in future studies. 


\section{References}

Bicknell AB (2008) The tissue-specific processing of proopiomelanocortin. J Neuroendocrinol 20:692-699. https://doi.org/ 10.1111/j.1365-2826.2008.01709.x

Bouw E, Huisman M, Neggers SJCMM, Themmen APN, van der Lely AJ, Delhanty PJD (2014) Development of potent selective competitive-antagonists of the melanocortin type 2 receptor. Mol Cell Endocrinol 394:99-104. https://doi.org/10.1016/j.mce.2014. 07.003

Brinkhof B, Spee B, Rothuizen J, Penning LC (2006) Development and evaluation of canine reference genes for accurate quantification of gene expression. Anal Biochem 356:36-43. https://doi.org/10.1016/ j.ab.2006.06.001

Burkhardt WA, Guscetti F, Boretti FS, Todesco AI, Aldajarov N, Lutz TA, Reusch CE, Sieber-Ruckstuhl NS (2011) Adrenocorticotropic hormone, but not trilostane, causes severe adrenal hemorrhage, vacuolization, and apoptosis in rats. Domest Anim Endocrinol 40: 155-164. https://doi.org/10.1016/j.domaniend.2010.10.002

Cerdá-Reverter JM, Agulleiro MJ, Cortés R, Sánchez E, Guillot R, Leal E, Fernández-Durán B, Puchol S, Eley M (2012) Involvement of melanocortin receptor accessory proteins (MRAPs) in the function of melanocortin receptors. Gen Comp Endocrinol 188:133-136. https://doi.org/10.1016/j.ygcen.2013.01.017

Clark AJ, Forfar R, Hussain M, Jerman J, McIver E, Taylor D, Chan L (2016) ACTH antagonists. Front Endocrinol (Lausanne) 7. https:// doi.org/10.3389/fendo.2016.00101

Cooray SN, Chung TT, Mazhar K, Szidonya L, Clark AJL (2011) Bioluminescence resonance energy transfer reveals the adrenocorticotropin (ACTH)-induced conformational change of the activated ACTH receptor complex in living cells. Endocrinology 152:495502. https://doi.org/10.1210/en.2010-1053

Dores RM (2013) ACTH antagonist peptides. US Patent Application US $8,524,664 \mathrm{~B} 2$

Dores RM, Londraville RL, Prokop J, Davis P, Dewey N, Lesinski N (2014) Molecular evolution of GPCRs: Melanocortin/melanocortin receptors. J Mol Endocrinol 52:29-42. https://doi.org/10.1530/ JME-14-0050

Galac S, Buijtels JJCWM, Mol JA, Kooistra HS (2010a) Effects of trilostane on the pituitary-adrenocortical and renin-aldosterone axis in dogs with pituitary-dependent hypercortisolism. Vet J 183:75-80. https://doi.org/10.1016/j.tvjl.2008.10.007

Galac S, Kool MMJ, Naan EC, Daminet S, Mol JA, Kooistra HS (2010b) Expression of the ACTH receptor, steroidogenic acute regulatory protein, and steroidogenic enzymes in canine cortisol-secreting adrenocortical tumors. Domest Anim Endocrinol 39:259-267. https:// doi.org/10.1016/j.domaniend.2010.07.001

Galac S, Reusch CE, Kooistra HS, Rijnberk A (2010c) Adrenals. In: A. R, Kooistra HS (eds) Clinical endocrinology of dogs and cats, Second. Schlütersche, pp 93-154

King JB, Morton JM (2017) Incidence and risk factors for hypoadrenocorticism in dogs treated with trilostane. Vet J 230:24 29. https://doi.org/10.1016/j.tvj1.2017.10.018

Livak KJ, Schmittgen TD (2001) Analysis of Relative Gene Expression Data Using Real-Time Quantitative PCR and the 2 $-\Delta \Delta$ CT Method. Methods 25:402-408. https://doi.org/10.1006/meth.2001.1262

Meijer JC, De Bruijne JJ, Rijnberk A, Croughs RJM (1978) Biochemical characterization of pituitary-dependent hyperadrenocorticism in the dog. J Endocrinol 77:111-118. https://doi.org/10.1677/joe.0. 0770111
Mountjoy KG, Robbins LS, Mortrud MT, Cone RD, Mountjoy KG, Robbins LS, Mortrud MT, Cone RD (1992) The Cloning of a Family of Genes That Encode the Melanocortin Receptors. Science 257:1248-1251. https://doi.org/10.2307/2880030

Nensey NK, Bodager J, Gehrand AL, Raff H (2016) Effect of novel melanocortin type 2 receptor antagonists on the corticosterone response to ACTH in the neonatal rat adrenal gland in vivo and in vitro. Front Endocrinol (Lausanne) 7. https://doi.org/10.3389/ fendo.2016.00023

O’Neill DG, Scudder C, Faire JM, Church DB, McGreevy PD, Thomson PC, Brodbelt DC (2016) Epidemiology of hyperadrenocorticism among 210,824 dogs attending primary-care veterinary practices in the UK from 2009 to 2014. J Small Anim Pract 57:365-373. https:// doi.org/10.1111/jsap. 12523

Potts GO, Creange JE, Harding HR, Schane HP (1978) Trilostane, an orally active inhibitor of steroid biosynthesis. Steroids 32:257267. https://doi.org/10.1016/0039-128X(78)90010-7

Ramsey IK (2010) Trilostane in Dogs. Vet Clin North Am Small Anim Pract 40:269-283. https://doi.org/10.1016/j.cvsm.2009.10.008

Reid LE, Behrend EN, Martin LG, Kemppainen RJ, Ward CR, Lurye JC, Donovan TC, Lee HP (2014) Effect of trilostane and mitotane on aldosterone secretory reserve in dogs with pituitary-dependent hyperadrenocorticism. J Vet Intern Med 28:443-450. https://doi. org/10.1111/jvim. 12276

Reusch CE, Sieber-Ruckstuhl N, Wenger M, Lutz H, Perren A, Pospischil A (2007) Histological evaluation of the adrenal glands of seven dogs with hyperadrenocorticism treated with trilostane. Vet Rec 160:219 224. https://doi.org/10.1136/vr.160.7.219

Ruggiero C, Lalli E (2016) Impact of ACTH signaling on transcriptional regulation of steroidogenic genes. Front Endocrinol (Lausanne) 7. https://doi.org/10.3389/fendo.2016.00024

Sanders K, Mol JA, Kooistra HS, Slob A, Galac S (2016) New Insights in the Functional Zonation of the Canine Adrenal Cortex. J Vet Intern Med 30:741-750. https://doi.org/10.1111/jvim.13946

Sanders K, Mol JA, Slob A, Kooistra HS, Galac S (2018) Steroidogenic factor-1 inverse agonists as a treatment option for canine hypercortisolism: in vitro study. Domest Anim Endocrinol 63:2330. https://doi.org/10.1016/j.domaniend.2017.11.001

Seelig S, Sayers G (1973) Isolated adrenal cortex cells: ACTH agonists, partial agonists, antagonists; cyclic AMP and corticosterone production. Arch Biochem Biophys 154:230-239. https://doi.org/10.1016/ 0003-9861(73)90053-2

Stassen QEM, Riemers FM, Reijmerink H, Leegwater PAJ, Penning LC (2015) Reference genes for reverse transcription quantitative PCR in canine brain tissue. BMC Res Notes 8:761. https://doi.org/10.1186/ s13104-015-1628-4

Stocco DM (1997) A StAR search: implications in controlling steroidgenesis. Biol Reprod 56:328-336. https://doi.org/10.1095/ biolreprod56.2.328

Vandesompele J, De Preter K, Pattyn I, Poppe B, Van Roy N, De Paepe A, Speleman R (2002) Accurate normalization of real-time quantitative RT-PCR data by geometric averaging of multiple internal control genes. Genome Biol 3:34-31. https://doi.org/10.1186/gb-2002-37-research0034

Willeberg P, Priester W (1982) Epidemiological aspects of clinical hyperadrenocorticism in dogs (Canine cushing's syndrome). J Am Anim Hosp Assoc 18:717-723

Yang YK, Ollmann MM, Wilson BD, Dickinson C, Yamada T, Barsh GS, Gantz I (1997) Effects of recombinant agouti-signaling protein on melanocortin action. Mol Endocrinol 11:274-280. https://doi.org/ 10.1210/mend.11.3.9898 